\title{
Post Secondary Education in a Prison Theory and Praxis
}

\author{
DR. STEPHEN DUGUID*
}

\begin{abstract}
A discussion of the replicability of the University of Victoria program at Matsqui Institution in terms of other prisons in North America. The theory behind the program is discussed, i.e., Kohlberg's theory of moral development and its relationship to behavior. The program is analyzed in terms of relations with the institution, type of courses, the necessity of establishing an alternative community within the prison and the type of staff necessary to maintain the program. The necessity of encouraging a "student identity" is stressed in order to facilitate the development process implicit in the program.
\end{abstract}

\section{RÉSUMÉ}

Voici un exposé sur la reproductibilité du programme de l'Université de Victoria à l'institution Matsqui, pour les autres prisons nord-americaines. La théorie sur laquelle ce programme est basé, celle de Kohlberg sur le développement moral et ses liens avec le comportement y est exposé. Le programme est analysé en fonction de ses rapports avec l'institution, le genre de cours, la necessité d'établir une communauté alternative à l'interieur de la prison et le genre de personnel necessaire pour maintenir un tel programme. $L$ 'auteur met l'accent sur le besoin d'encourager une "identité d'étudiant" qui va faciliter les processus de développement inhérents à ce programme.

This paper is a description of an academic program within a penal institution: the University of Victoria program at Matsqui Institution, Abbotsford, British Columbia. It has a further purpose, however. The Matsqui program has been described by outside observers as "successful", "exceptional", and "unique in Canada, perhaps in North America". It may, therefore, be useful to examine it in terms of a model, and analyze its essential components for possible wider application.

The discussion begins with a look at the theory behind the program, the assumptions

*University of Victoria. 
upon which it builds a series of specific practices. This is not done to detract from the practical aspects of the paper, nor to cloud the issue with academic jargon, but to display one of the very real strengths of this particular program: the conjunction and interdependence of theory and praxis.

The involvement of the University of Victoria with correctional education began in 1972 , with a pilot project at the British Columbia Penitentiary and Matsqui Institution. The project was based on the work of Dr. T.A.A. Parlett who had carried out a similar project at William Head Institution aimed at demonstrating the connection between education and cognitive and personality changes among prisoners. By 1973, the project had been formalized through a contract between the University and the Canadian Penitentiary Service.

From its inception the program has concentrated in the humanities and social sciences, starting with a few courses in English, history and psychology and then expanding to include a full range of courses in these fields plus sociology and anthropology. In the past three years the program at Matsqui has expanded to the point of being able to offer a $\mathrm{BA}$ degree to prisoner/students who are unable to transfer to a university campus. All the courses are fully accredited and may be transferred to any college or university in Canada. While not aimed at providing specific post-secondary vocational training, the academic program does provide the student with the ability to obtain a degree and thus prepare himself for a career change.

Besides this academic function, the University of Victoria program operates on two other levels. One of these is centered on the theory of human change or development which lies at the very base of the program itself. Based on the work of Lawrence Kohlberg and Thomas Lickona as well as the recent work of Yochelson and Samenow, the program is concerned with the broad issue of moral development. ${ }^{1}$ The assumption is that much of criminal activity stems from an underdeveloped moral structure or moral reasoning ability. Further to this, it is held that cognitive development is a necessary step in moral development, that to advance from one stage of moral development to another, more 'social' stage, one must be able to reason in a more sophisticated and analytical manner. ${ }^{2}$ Through the medium of university courses, the program attempts to facilitate that cognitive development, enhance reasoning abilities and thus lay the groundwork for the adoption of a more socially acceptable sense of morality in the individuals concerned. The aim is by no means to produce saints, but rather to strive for a less egocentric individual with a more balanced vision of how the world works and the role and responsibilities of the individual within that world.

Finally, the third level at which the program operates concerns the creation of an alternative community within the prison. The aim is to acquaint the prisoner/student with an alternative set of social relationships, with individuals unlike those he may have known before, and with ideas and social practices which challenge long held beliefs. This is done in several ways, each of which is discussed in detail later in this paper. Briefly, the first requirement is as much isolation as possible from the institution itself since its personnel and practices simply mirror the moral and physical world the students are familiar with. Secondly, the program is staffed with individuals who are neither the same as nor aloof from the world of the prisoner/student. The aim is neither to condemn nor idolize the self-view of the prisoner, but rather to challenge it in order to encourage self-directed 
change. Thirdly, an attempt is made to expose the students to as much cultural input as possible that is new or out of the ordinary, including film, music, art and current events. Finally, a sense of community is encouraged by the development of a sense of corporate responsibility through student councils, students as teaching assistants, group decisionmaking and a general refusal to let institutional politics or mores govern life within the university program.

In discussing the ideal structure for such a program, the twin goals being pursued must be kept in the forefront: cognitive development to facilitate moral development and the attempt to translate that cognitive/moral growth into changed behavior. ${ }^{3}$ Conversely, it can be argued that the goals might be reversed, i.e., changed behavior through the rules of the alternative community which when coupled with cognitive growth results in moral growth. Either way, the structure necessary to accomplish these ends has three fundamental aspects: the academic program, relations with the institution and the nature of the staff.

The first problem that confronts any program within a prison is one of credibility. Prisoners are increasingly faced with a wide spectrum of programs within institutions, most of which are greeted with cynicism or rejection. Since there exists an implicit hostility and mistrust between prisoners and the prison, any program sponsored or administered by that institution starts out with a severe handicap. The first requirement, therefore, is that it be contracted to an institution outside the penitentiary system. ${ }^{4}$ Because the hostility and mistrust of the prisoners lessens with distance, the terms and administration of the contract should be handled through the headquarters of the penitentiary system, not its regional offices or the institution concerned. This procedure entails certain dangers, namely the isolation of the program from the bureaucratic self-interest of the local penitentiary system representatives, but the benefits which accrue from the students' increased acceptance of the program are more important in the long run. ${ }^{5}$

Ideally, the contract should be made with a university rather than a junior or community college. The issue of credibility is once more paramount here, the prisoner/students being very status conscious and more sensitive than most to the prestige attached to affiliation with a university. The program within the institution should be a genuine offcampus program of the university, with its own staff and administrative structures and should be represented on campus by a faculty member of sufficient standing to safeguard its interests vis-a-vis the administrative structures of the university. A program such as this will by its very nature be seeking special considerations from academic bodies such as the university registrar and the various departments concerned. As anyone familiar with university bureaucracies can attest, such periodic rule-bending can be difficult without friends in high places. ${ }^{6}$

Most post-secondary education within prisons consists of what might be called "dropin" programs, with instructors from colleges and universities offering individual courses with varying degrees of organization, planning or control. These programs have several inherent problems. First, the course offerings tend to show little coherence, selection being based on who is willing to travel to the prison or who has the time. Contract instructors with no on-going university affiliation present a problem in terms of quality, their only concern being the individual course they are offering, having no stake in either the prison program or the standards of the university. To avoid this, the prison program should have a full-time staff, selected for their academic qualifications as well as their particular affinity 
for and interest in teaching in the prison environment. In addition, there should be instructors from the main campus and contract instructors hired to teach specific courses. Thus the program has continuity, quality control from the various university departments and a continual influx of new, part-time contract instructors.

The academic course offerings are the core of the program and the chief deus ex machina for furthering the cognitive development which is its base justification. Most scholars in this field agree that the fields of history (or social studies in general) and literature are the most effective in enhancing moral reasoning ability. ${ }^{7}$ While philosophy and mathematics are more appropriate disciplines for teaching abstract reasoning, history and literature have the advantage of providing content for the exercise of reasoning skills. In addition, there are implicit moral and ethical issues in these disciplines which are not necessarily present in others.

The core areas of history and literature should be supplemented by an equal emphasis on the social sciences (sociology, psychology and anthropology) as well as science courses when practicable. Again, for the sake of credibility, the course selection must be as reflective of a traditional liberal education as possible. The social science courses, perceived as 'relevant' and 'practical', are generally most popular, usually necessitating making the humanities required courses to ensure their maximum effect.

Because so many students enter the university program with poor academic backgrounds, special non-credit courses should be part of each student's initial term. ${ }^{8}$ A remedial course in English composition is essential to at least half of the new students in the Matsqui program. In addition, a general course in study skills should be mandatory for all new students. If mathematics or science courses are to be offered for credit, then a mathematics upgrading course is also a necessity since few will have successfully completed pre-university high school mathematics.

All of these non-credit courses should, if possible, be taught by the prisoner/students themselves, either men who have earned a BA degree or who have special qualifications in the field. Not only does this provide meaningful employment and experience for successful students, but it gives the new student an excellent introduction to the program. ${ }^{9}$

The academic program should operate as independently of the prison as is possible. Ideally there should be a separate building, removed from the centre of the institution. Prison staff in the area should be kept to a minimum and the students allowed to remain in the school area during the entire day. This allows the prisoner/student to be more decisively a 'student' as well as facilitates academic work. Above all, it serves to dissociate the academic program from the prison. If this physical distance cannot be achieved then all steps possible should be taken to minimize interaction with the rest of the prison, both staff and prisoners.

The term "prisoner/student" has been used quite deliberately throughout this paper. The environment imposes the former and it is the aim of the academic program to strengthen and nurture the latter. Very little change or effect can be accomplished as long as the individual remains primarily a prisoner in terms of self-view. With the emphasis on the alternative community a major part of the academic program, this dualism is almost automatic for those men who choose to participate. It is the responsibility of the university staff to do all that it can to maximize the opportunities for the student role to be manifest. Since the prison is in most ways a "total institution", this is difficult to accomplish. The 
distance, physical, administrative and psychological, is important. Also important are proper learning facilities such as classrooms, a library, study areas, typing rooms and areas for relaxation, again approximating that of the university.

Men are in prisons because of their behavior and one of the purposes of prisons is to persuade men to alter behavior. Since very few prisoners admit to being at fault or wish to alter future behavior, they erect a variety of sophisticated defense mechanisms aimed at warding off such attempts at change. One of the most powerful of these mechanisms is the very fact of being a prisoner, the pervasive self-view of the prisoner against society, i.e., the prison. One way to break through these defenses is to highlight an alternative role, in this case the student, which in turn opens the individual to a variety of influences which can affect behavior.

Environmental and structural factors are not enough, however, to make such a program work. It is the staff of the program that will be the determining factor within either a perfect or imperfect structure. ${ }^{10}$ The position of the teaching staff in the prison setting is unique. First, they have no power, since power in the prison situation is related to an ability to get one out of prison or keep one in prison. Being contracted from a university, they have no mechanism beyond letters of reference to effect a release and being denied disciplinary powers they cannot prolong an individual's stay. This frees the student from much of the manipulation that must necessarily go on between prisoner and institutional staff, opening up the possibility of more genuine relationships. Secondly, for many of the students, the instructor may be one of the very few 'straight' people he will ever have been in close contact with, thus creating a potential modeling situation.

Two speculations spring from this. First, is there an 'ideal-type' instructor in a prison and, second, what should an instructor do to take advantage of the opportunities provided by the situation? The first question is a difficult one to answer. Assuming what Kohlberg poses on stages of moral development, one can agree with him that a Stage 4, "law and order" oriented instructor would not be of much value. Moral development cannot be encouraged in an authoritarian setting, but rather requires an atmosphere and organization which exhibit what Kohlberg calls "'post-conventional" features, his stages 5 and $6 .^{11}$ Moral development within the cognitive framework requires a relationship of mutual respect between teacher and student, authoritative but not authoritarian. Instructors must therefore tread between the poles of permissiveness and authoritarianism.

For the part-time staff, academic excellence is the first requirement. Once again, credibility is the key issue. The students will be constantly on the alert for signs of condescension, for a dilution of the content of courses to meet the rather special environment. Course work-loads, reading assignments and examinations must be as close to those offered on campus as possible. This is especially important for instructors in the social sciences, since they may be more susceptible than others to taking into account the "deprived" nature of many of their students. ${ }^{12}$

The full-time staff must follow all of the above, but have further responsibilities. It is their function to establish the tone or atmosphere of the program. Much of this is done through relations with individual students, making the student/staff ratio an important factor in the program's success. The number of students should not exceed twenty per full time staff member, that ratio being a practical limit for close contact. Since the full 
time staff are also responsible for administering the program, it is their job to establish as democratic an administration as possible, again providing a vivid contrast to the rest of the institution.

The prison environment creates by its very nature an extreme form of individualism among the prisoner/students which can be countered by a deliberate effort to share responsibility. Since the prisoner/students will assume that responsibility or authority is not to be shared and will therefore willingly accede to the imposition of authority, it requires conscious effort on the part of the staff not to comply with this tendency. Student councils, committees and assignment of responsibilities to individual students all work to create this democratic environment. Above all, any changes within the academic area, whether physical, administrative or academic, should be discussed with the student body or its representatives. The prison is their home, yet despite their being adults they are given no say in its rules, structure or physical shape. The academic program must provide a contrast.

Finally, it is the job of the full time staff to be constantly innovative. Prisons are repressive, but even more than that they are boring. The academic program, again to emphasize the contrast, should be not only democratic but also exciting and innovative. Besides the introduction of new courses each year in areas such as science or theatre, there should be film programs with parallel discussion groups, a student newspaper or journal, sports teams to compete with other institutional teams, social events for students and their friends/family, periodic environmental changes within the university area and whatever else is possible within the rules of the institution and the parameters of the budget. $^{13}$

The theoretical premises described earlier in this paper, if valid at all, are universally applicable to the field of correctional education. The specific university model discussed in the remainder of the paper must in fact be quite flexible if it is to have more than a particular applicability. Questions of environment and budget will effect its implementation in other settings. Yet, there are it seems certain minimum requirements. First, the structure or design of the program must be free of control by the prison administration. Second, the program must have academic credibility among the students. Finally, the staff must be carefully selected and represent the proper mix of full time and term instructors.

\section{FOOTNOTES}

1. For an excellent summary of this work, see Thomas Lickona, ed., Moral Development and Behavior: Theory, Research and Social Issues (NY: Holt, Rinehart, Winston, 1976). See also Samuel Yochelson and Stanton Samenow, The Criminal Personality (NY: James Aronson, 1976).

2. Thus the "medical model" is not part of such a program. ". . the medical-theraputic model of criminality which has emphasized rehabilitation by expunging inappropriate behavior to replace it with more appropriate behavior, has been open to serious questioning on theoretical, practical and ethical grounds. This model has obscured the nature of criminality by emphasizing the study of personality and of social context in defining criminal and non-criminal behavior. It has failed to consider thought patterns in defining criminal behavior. ..."J.D. Syers, "Perspective on Education in Prisons", paper prepared for presentation to members of the Ontario Institute for Studies in Education Review of Penitentiary Education and Training, 1978/9, Kingston, Ontario, Oct. 26, 1978, p. 2. 


\section{Post-secondary Education in a Prison: Theory and Praxis}

3. It should be pointed out that cognitive development remains a necessary but not sufficient condition for moral development and that the link between moral development and behavior is a very controversial issue among theorists. See Justin Aronfreed's attack on the cognitive model and Lawrence Kohlberg's defence in C.N. Beck, et. al., Moral Education: Interdisciplinary Approaches (Toronto: Univ. of Toronto pr., 1971).

4. Some of these fears are well founded since institutional interference can be crippling to an educational program. "Some correctional authroities wish to 'supervise' education. This they do by operating the program themselves, by having correctional staffs 'participate' in the supervision of student behavior, by 'approving' of curriculum, etc., by establishing rules of student and staff behavior, etc. A caseworker may have to approve the enrollment of his 'clients' in specific classes; correctional of ficers may dictate student conduct in class, etc." Michael Reagen and Donald Stoughton, School Behind Bars (Metuchen, N.J.: Scarecrow pr., 1976), p. 18.

5. See Marjorie Seashore and Steven Haberford, Prisoner Education: Project Newgate and Other College Programs (NY: Praeger, 1976), p. 157.

6. Examples of such rule bending abound in the University of Victoria program. For instance, the program advances its term beginnings and endings by one month to get a head start on the university registration procedures, offers four month rather than eight month courses as on campus, regularly asks for special dispensations re late adds and drops in light of the irregularity of the students' lives and frequently asks the university to set aside its forced withdrawal procedures for certain students. It should be noted that these special considerations are always procedural and never academic.

7. Lawrence Kohlberg, "The Cognitive-Developmental Approach to Moral Education" and Brian Crittendon, "A Comment on Cognitive Moral Education", in the Phi Delta Kappan, June 1975. Crittendon notes that in addition to promoting the growth of intellectual and moral virtues, the moral educator should also be concerned with developing an attitude of "benevolence toward other human beings" as well as the ability to discern the feelings of others and the waysin which one's actions affect, or are likely to affect them. He argues that this expansion of the "sympathetic imagination" is best accomplished through the proper study of history and the arts, particularly literature and drama. p. 697 .

8. While grade 12 equivalency is encouraged, in fact an open admission policy is best suited to the program's goals. As Seashore points out, it is the prisoners with only "latent potential" that otherwise would not obtain a college education in the "free world" that have the greatest potential for being changed in terms of life chances and moral development. Seashore, p. 153.

9. Reagen and Stoughton, p. 21. The authors note that the use of prisoners as teachers is part of the self-actualizing process. The teaching prisoner is an example to the others and is leading himself away from past behavior while he "inspires others to the same end."

10. One survey notes that "...the key element is not educational technology, rather it is the correctional teacher. In prison education, the teacher has a much bigger task than the ordinary teacher." Reagen and Stoughton, p. 80.

11. Edmund Sullivan and Clive Beck, "Moral Education in a Canadian Setting", Phi Delta Kappan, June 1975 , p. 700 .

12. "Graduation from one level to the next must be based on standard educational requirements and performance criteria used by accredited institutions. Only in this kind of program will the students have the satisfaction that their accomplishments are not only intrinsically but also extrinsically valuable in that they qualify them for a higher step, are widely respected, and, therefore, transferable to other settings." Seashore, p. 26.

13. The importance of this atmosphere is stressed throughout Seashore and Haberfield's assessment of university programs in American institutions. They note the importance of "social integration" in drop-out rates on normal university campus' and argue that this integration can only be established by breaking the hold of the prison environment within the education program. p. 69, p. 149 . 